\title{
An Empirical Analysis on Organizational Integration and Its Effect on the Internationalization of Exporting Firms in North Cyprus
}

\author{
Tayfun Turgay \\ Graduate School of Social Sciences, The American University, Girne \\ Karaoglanoglu Campus, Kyrenia, North Cyprus \\ Tel: 90-392-650-2000Ｅ-mail: tayfunturgay@gau.edu.tr \\ Mehmet Ali Ekemen (Corresponding author) \\ Dept. of International Business Mgmt., The American University, Girne \\ Karaoglanoglu Campus, Kyrenia, North Cyprus \\ Tel: 90-392-650-2000_E-mail: mekemen@gau.edu.tr
}

Received: Dec. 6, 2012 Accepted: December 30, 2012 Published: January 1, 2013

doi:10.5296/jmr.v5i1.2807 URL: http://dx.doi.org/10.5296/jmr.v5i1.2807

\begin{abstract}
The role of organizational integration within and between organizations and the impacts of integration on organizational growth and performance have been studlied extensively in literature. As a building block of supply chain management, organizational integration has positive significant effect on the performance of the organization. Sharing information, gathering business intelligence and establishing collaboration among functional departments and between business partners are also expected to improve the internationalization process as well as the international performance of the organization. We propose and test a model of the relationship between organizational integration and international performance of the organization by using empirical data. Our model differs from past studies in that integration is viewed as four types; functional integration among departments, customer integration, supplier integration and distributor integration. It is aimed to discover the role of each type individually in this model, rather than classifying them as inter- and intra-organizational integration. Our findings show that organizational integration impacts both international commitment and export performance by promoting four measures of integration. These
\end{abstract}


findings reveal the importance of organizational integration for exporting companies in promoting information and business intelligence sharing, and collaborating among functional departments and between business partners.

Keywords: Organizational integration, Supply chain management, Internationalization, International commitment, Export performance 


\section{Introduction}

The supply chain management addresses that enhancing the service or product provided to the customers at a lower cost requires close relationships among business partners. The philosophy requires change from short-term interactions to long-term relationship by establishing partnership among firms to create strong supply chains. It is generally stated that increased collaboration among supply chain firms leads to lower cost and enhanced service performance (Holweg et al., 2005). Integration begins with customers and extends back through the firm from delivery of products to their manufacturing and purchase of raw materials, as well as the interaction with suppliers of materials. Thus, the integration both within the organization and among the organizations is required for the maximization of performance (Vereecke and Muylle, 2006).

The effort of coordinating operations across all processes of a business has become known as supply chain management, SCM (Stadtler, 2009). In the last decade, the concept of supply chain management has been expanded to outside the boundaries of the firm by making customer and supplier integration as parts of the process. Firms are developing close relationships with major customers and are improving collaboration with suppliers. They aim to extend the control of the firm over each stage of the supply chain, from procurement of raw materials to after sale services. The needs and capabilities of suppliers and customers are incorporated into strategic planning of the firm, aiming to maximize satisfaction of the customers and to achieve improved organizational performance.

Globalization has rapidly changed the face of business over the past decade. Many firms have challenges in a complex business environment, driven by globalization, the international markets and the requirement for higher efficiency, effectiveness and competitiveness which relies on innovation and knowledge. This causes increased pressure upon the firms, especially manufacturing firms that now compete globally (Cagliano \& Spina, 2002).

Through organizational integration, exporters are better able to compete in international markets which are often beyond their individual capabilities (Waite \& Williams, 2009). Osarenkhoe (2010) proposes that utilizing collaboration among business partners is improving competitiveness in environments where uncertainty exists. Both internal and external integration help managers to understand market complexities (Olkkonen, Tikkanen \& Alajoutsijärvi, 2000), and facilitate competitiveness in export markets (Gilmore et al., 2006). As a solution for an industry's international competitiveness, Porter (1998) suggests that national or regional economies are more likely to succeed in international business if interrelated firms are grouped in close proximity.

Studies have found organizational integration to be positively linked to organizational performance (Vickery et al., 2003; Stank et al., 2001). Less attention has been paid to the direct impact of organizational integration on international performance.

The goal of this research is to extend knowledge on how organizational integration impacts international performance. Specifically, we propose and test a model of the relationships between organizational integration; which is measured as functional, customer, supplier and 
distributor integration, as well as international performance; which is measured as international commitment and export performance.

We focus on integration as the independent variable which is expected to have positive significant effect on international performance variables; international commitment and export performance. Organizational Integration is considered as a critical element of SCM and has received a great deal of attention in literature. Our model extends knowledge in this area by assessing each form of integration individually in SCM, unlike past researches that had studied the integration in two broad classifications as inter- and intra-organizational collaboration. This enables us to provide deeper insights about integration and its relationship to international performance. The model and constructs used in our study are directly derived from literature.

Our findings show that each type of integration individually and collectively impacts both measures of international performance directly. These results have important implications for both firms and researchers as they provide insights into the mechanism of how organizational integration impacts international performance and the inherent complexities of integration.

\section{Theoretical Background}

\subsection{Organizational Integration}

The need for integration in the value creation process is not a new concept. The theoretical background for supply chain management starts from Forrester's work on system dynamics (1961). This theory addresses that creating value by business is not limited with the boundaries of the organization, but involves integration among parties of supply chain, such as suppliers, manufacturers and customers (Stevens, 1989). Also, Staude (1987) suggested a systems approach for integrating both inter- and intra-organizational activities. The further development on value creation process was made by Porter $(1980,1985)$ who states the use of "linkages" within a firm's value chain and between the value chains of its suppliers and customers. The use of these "linkages" requires integration, collaboration, and coordination across firm's functions and throughout the supply chain, where it is expected to result in superior performance (Tan et al., 1998).

In the settings of supply chain, integration should be designed in a way that includes the members of supply chain, such as suppliers and customers. The firm must invest in relationships and share the resources for improved integration. For the effective integration, it is important to share mutual understanding, a common vision and collective goals among supply chain members (Kahn \& Mentzer, 1996).

Hammer and Champy (1993) states three major forms of integration in supply chain management; intra-organizational process integration, inter-organizational collaborative integration and inter-organizational operational integration. The first form of integration, intra-organizational process integration, is the integration of cross-functional processes within the firm, such as between procurement, production and marketing (Shapiro, Rangan \& Sviokla, 1992). Intra-organizational process integration requires the functional departments to act as part of a coordinated and integrated process within the firm rather than individual units 
(Hammer \& Champy, 1993). This means that customer demand and firm's supply capabilities should be aligned and balanced to create optimized value for customers. It is also stated that internal integration is a requirement for successful external integration of a firm with suppliers and customers (Kanter, 1994). The firm aligns its functions to the uncertainties and linkages with customers and suppliers through internal integration and matches external conditions which enable inter-organizational integration.

The second form, inter-organizational collaborative integration, is the close relationships and collaboration of a firm with both suppliers and customers (Bowersox, 1990). Collaborative integration refers to establishing strategic alliances in between firm and business partners; such as suppliers and customers. The main concern in this integration is behavioral, communicational and interactive relationships among supply chain members. As such, the members of supply chain are components of overall value offered to customers and they must act coordinated to produce superior value to maximize satisfaction.

The third form, inter-organizational operational integration, involves optimization of resource flows between firm and supply chain members (Hines, 1993). This form of integration focuses on minimizing costs, elimination of intermediate production steps, reducing waste and redundancy, and optimizing business processes through external integration (Treacy \& Wiersema, 1993).

\subsection{Internationalization and International Performance}

All firms are facing the effects of increased international competition due to strong economic trends towards globalization. However, globalization is also providing new opportunities for firms which are willing to expand their operations into international markets. Therefore, internationalization is an important issue for all firms, regardless of size, industry or strategy of the firm.

The internationalization of a firm is a process of steps which will be taken in sequential order. Firms utilize a progressive learning process through internationalization (Johanson \& Vahlne, 2003). These firms gain knowledge of doing business in international markets. The process of internationalization starts by establishing intention into geographically and culturally diverse markets, then follows as increasing the firm's level of commitment to these markets step by step based on the market knowledge. The commitment of the firm will be initiated starting with having representative sales agent (importer) in foreign market and developed through establishing sales office and then manufacturing facility in target market.

According to Buckley and Ghauri (1999), internationalization of a firm will be achieved through increasing the level of international involvement. It is assumed that the profitability of a firm is enhanced by internationally expanding its operations. The firm obtains potential benefit from being international as it gains more knowledge and experience in the process of internationalization.

The growth of a firm in the internationalization process is explained by the knowledge-based theory. It states that although a risk involved in using firm's resources in international activities, these operations provide learning of specific knowledge about foreign markets 
through experiences. Therefore, the risk will be reduced by increased knowledge of market and the firm will be encouraged to allocate more resources into experienced market (Eriksson, 2000).

The internationalization process of a firm also requires both internal and external organizational integration. The strategy of internationalization must fit with organizational structures (Chandler, 1962). It is also stated that the firm's organizational structure must match with suppliers and customers to establish integration. The integration among supply chain members through integrated processes and collaboration will provide synergy that can be used as strategic competitive advantage in international markets.

Exchanging information about international markets, host countries or regions, plays an important role in the international performance of a firm. The firm exchanges information with suppliers and customers to be used in international activities. Many researches argue that learning is one of the main forces in internationalization (Benito \& Welch, 1994). Firms rely on their networks to acquire information about new markets and to identify ways on how to overcome barriers to operate in these new markets. Having more members in business networks increases the chances of getting the required information to enhance international performance (Chetty \& Campbell-Hunt, 2003).

\subsection{Information Systems}

The intricate nature of supply chain management asserts certain requirements on the supply chain management information system. These information systems are used to coordinate information among internal and external clients, suppliers, distributors and other partners in the supply chain. It plays an increasingly vital part in the ability of companies cost reduction and improved responsiveness of their supply chain (McLaren et al., 2004). Several varieties of information systems for supporting supply chain functions exist, however the performance of these systems may differ dramatically. An incorrect choice in this system usually has an adverse effect on the supply chain management process. Employing a cross functional information system eliminates such issues at both strategic and tactical levels. Businesses require process-oriented support systems that are able to link across functions for effective supply chain management. Information systems containing only limited functionality of supply chain management cannot guarantee sufficient information essential to the decision-making process.

The most popular alternative among the information systems for supply chain management is the Enterprise Resource Planning (ERP) approach. Unfortunately, investment in ERP systems is not as cost-effective as initially expected. The first cause for this stems from the fact that ERP assumes business processes are re-engineered in accordance with ERP requirements, which is some cases is not possible due to the failure of company management's comprehension of the significance. Another cause is again related to the miscomprehension of the potential of ERP systems and/or the overestimation of information system functionality (Soshko, 2011). 


\section{Conceptual Model and Research Hypotheses}

\subsection{Model}

\subsubsection{Independent Variable: Organizational Integration}

Most firms are trying to integrate the internal and external processes of the firm in order to increase the value offered to customers by reducing waste, redundancy and increasing efficiency. The goal is to achieve the lowest cost without sacrificing customer satisfaction. Integration contributes to these performance improvements (Kahn \& Mentzer, 1998).

In literature, organizational integration is defined as the extent to which distinct and interdependent organizational components; including organizational departments and business partners, constitute a unified whole (Barki \& Pinsonneault, 2005). Another definition for organizational integration is effective, mutually shared processes between functional departments and among business partners which have mutual understanding, a common vision, share resources, and achieve collective goals (Stank et al., 2001). In addition, Porter (1985) describes organizational integration as a system consists of internal and external processes.

Using this distinction, organizational integration is subdivided into internal integration and external integration where internal integration is the internal processes and external integration is integration of external processes. For the purpose of emphasizing the unique role of each form of integration, we used one measure as a construct of internal integration and three measures as constructs of external integration. Both internal and external integration were assessed in subjective manner.

As a measurement of internal integration, respondents are asked to assess the extent of exchanging information and collaborating among functional departments of an organization which is known as (1) functional integration.

The external integration was measured by asking the respondents to indicate the extent of exchanging information and collaborating between the firms and (2) customers, (3) suppliers and (4) distributors.

\subsubsection{Dependent Variable: International Performance}

Many studies suggest that the international performance of a firm carries multidimensionality and should be measured by a variety of indicators (Katsikeas et al., 2000). Lumpkin and Dess (2001) addresses that subjective measures of performance can accuratelly reflect objective measures. Therefore, the indicators of international performance could be objective or subjective.

In this study, the international performance is measured on one objective and one subjective indicator; (1) international commitment as a ratio of a firm's exports to total sales of the firm, and (2) export performance as the firm's assessment of the overall performance of its export activities relative to major competitors. These are both among the most commonly used measures in this context (Katsikeas et al., 2000). 


\section{Macrothink}

Journal of Management Research

ISSN 1941-899X

2013, Vol. 5, No. 1

This study focuses on the relationship between a firm's organizational integration and its international performance. The organizational integration in terms of functional, customer, supplier and distributor integration is assumed to have a positive significant effect on both international commitment and export performance which refers to international performance.

Given the above discussion, we formulated the following hypotheses:

Hypothesis 1: Functional integration has a positive significant effect on international commitment.

Hypothesis 2: Customer integration has a positive significant effect on international commitment.

Hypothesis 3: Supplier integration has a positive significant effect on international commitment.

Hypothesis 4: Distributor integration has a positive significant effect on international commitment.

Hypothesis 5: Functional integration has a positive significant effect on export performance.

Hypothesis 6: Customer integration has a positive significant effect on export performance.

Hypothesis 7: Supplier integration has a positive significant effect on export performance.

Hypothesis 8: Distributor integration has a positive significant effect on export performance. 
Figure 1 depicts the hypothesized relationships among the two major concepts under investigation in addition to a number of sub constructs.

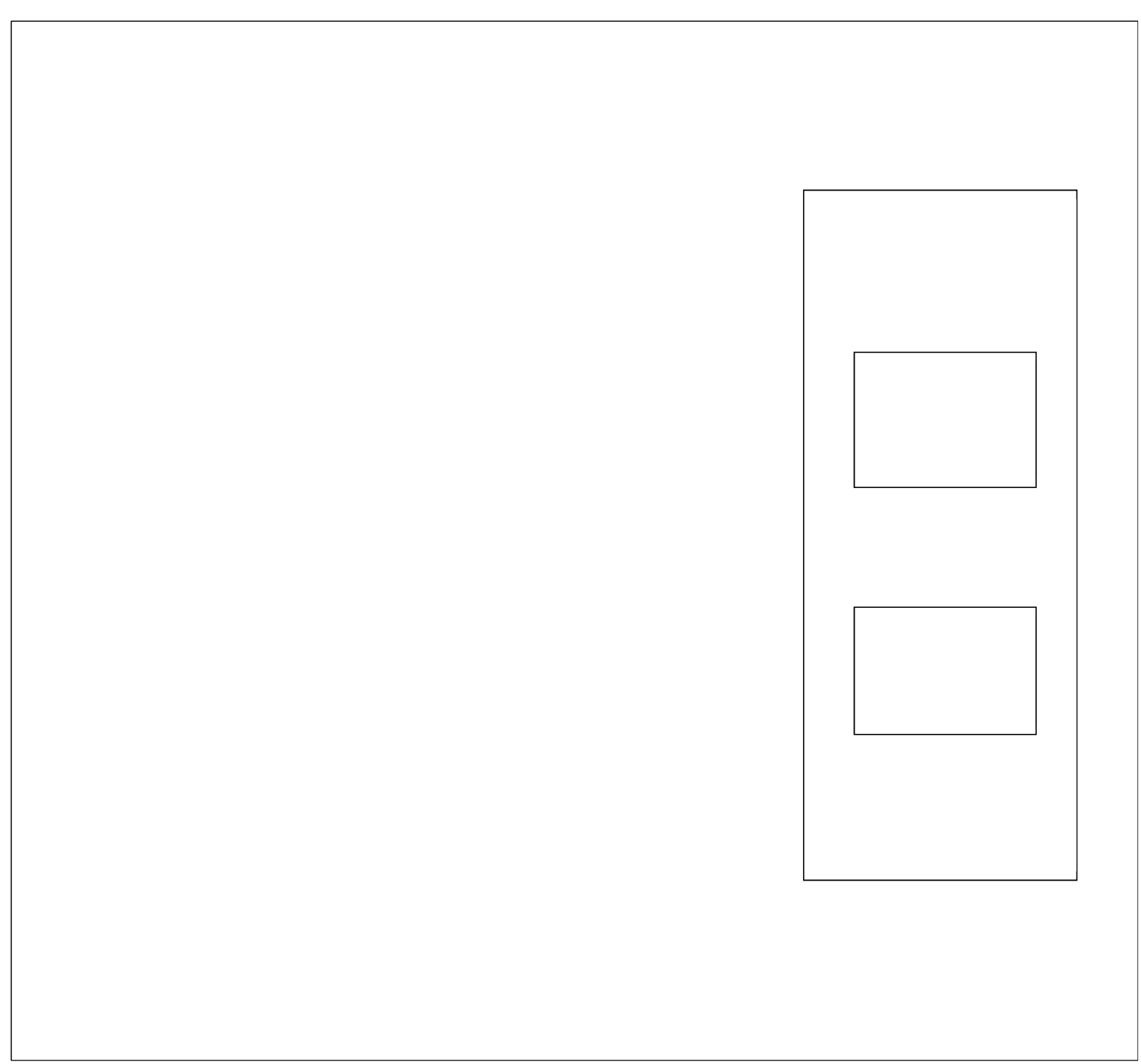

Figure 1. The conceptual model of the study 
A summary of the indicators used, together with their scales and labels, is provided in Table 1.

Table 1. The items, scales, labels and constructs of the model

\begin{tabular}{|c|c|c|c|c|}
\hline \multicolumn{2}{|c|}{ Constructs } & Questionnaire Items & Scale & Label \\
\hline \multirow{3}{*}{$\begin{array}{l}\text { Internal } \\
\text { Integration } \\
\text { (II) }\end{array}$} & \multirow{3}{*}{$\begin{array}{l}\text { Functional } \\
\text { Integration } \\
\text { (FI) }\end{array}$} & Collaboration among departments in strategic planning & 1 to 5 & FI1 \\
\hline & & Established integrated database among departments & 1 to 5 & FI2 \\
\hline & & Sharing operations info among departments & 1 to 5 & FI3 \\
\hline \multirow{9}{*}{$\begin{array}{l}\text { External } \\
\text { Integration } \\
\text { (EI) }\end{array}$} & \multirow{3}{*}{$\begin{array}{l}\text { Customer } \\
\text { Integration } \\
\text { (CI) }\end{array}$} & Conducting marketing research & 1 to 5 & $\mathrm{CI} 1$ \\
\hline & & $\begin{array}{l}\text { Identifying needs and expectations of customers in } \\
\text { new product development process }\end{array}$ & 1 to 5 & $\mathrm{CI} 2$ \\
\hline & & $\begin{array}{l}\text { Receiving feedback from customers about level of } \\
\text { satisfaction or dissatisfaction }\end{array}$ & 1 to 5 & $\mathrm{CI} 3$ \\
\hline & \multirow{3}{*}{$\begin{array}{l}\text { Supplier } \\
\text { Integration } \\
\text { (SI) }\end{array}$} & Sharing operations info in between firm and suppliers & 1 to 5 & SI1 \\
\hline & & Collaboration with suppliers in operations planning & 1 to 5 & SI2 \\
\hline & & $\begin{array}{l}\text { Achieved flexibility in operations caused by } \\
\text { collaboration with suppliers }\end{array}$ & 1 to 5 & SI3 \\
\hline & \multirow{3}{*}{$\begin{array}{l}\text { Distributor } \\
\text { Integration } \\
\text { (DI) }\end{array}$} & Sharing operations info between firm and distributors & 1 to 5 & DI1 \\
\hline & & $\begin{array}{l}\text { Collaboration with distributors in formulation of } \\
\text { marketing strategy }\end{array}$ & 1 to 5 & DI2 \\
\hline & & $\begin{array}{l}\text { Established common measures for performance among } \\
\text { firm and distributors }\end{array}$ & 1 to 5 & DI3 \\
\hline \multirow{2}{*}{$\begin{array}{l}\text { International } \\
\text { Performance } \\
\text { (IP) }\end{array}$} & $\begin{array}{l}\text { International } \\
\text { Commitment }\end{array}$ & Export / total sales $(\%)$ & 0to100 & IC \\
\hline & $\begin{array}{l}\text { Export } \\
\text { Performance }\end{array}$ & $\begin{array}{l}\text { Perceived export performance compared to } \\
\text { competitors }\end{array}$ & 1 to 5 & EP \\
\hline
\end{tabular}




\subsection{Data Collection}

The empirical data used in this study is drawn from a dataset collected using as undisguised -respondents were informed about the purpose of the study - and structured - the same questions are administered to every respondent, questionnaire. The survey was conducted by filling the questionnaires in face to face interviews in the summer of 2012.

The questionnaire was developed by using five-point Likert scales to minimize response time and effort (Knight \& Cavusgil, 2004). Pretests regarding the clarity of the survey items were conducted with ten exporting companies.

Our study relies on the primary data collected by interviewing a respondent, single key informant, from each one of 70 exporting firms separately. We followed Huber and Power's (1985) guidelines on how to get quality data from single informant to maximize accuracy and reliability. Organizational integration and international performance are operationalized from the perspective of the top managers who are typically the most knowledgeable persons regarding their companies' strategies and overall business situations. Most of our respondents had titles such as managing director, general manager and export manager, indicating a senior position in the firm.

A total of 70 companies were identified as the total number of registered exporters in North Cyprus who had exporting activities in the year 2011. The contact information of these companies were obtained from KOBIGEM, which is a center that aims to improve the performance of small and medium sized firms under the supervision of the Ministry of Economy. These 70 companies were reached by telephone and were found eligible to answer the questionnaire. Eligibility and the identity of the most suitable key informants were obtained during the telephone conversation.

\subsection{Data Analysis}

The model was estimated by conducting multiple regression analysis, which is a method to predict dependent variable by linear combination of the multiple independent variables. Multiple regression analysis was seen as the most appropriate technique for the research objective and limitation in sample size. In our model, two linear regression equations were developed to be used in assessing the relationship between organizational integration and international performance. These are:

$$
\begin{aligned}
& \mathrm{IC}=\beta_{1} \mathrm{FI}+\beta_{2} \mathrm{CI}+\beta_{3} \mathrm{SI}+\beta_{4} \mathrm{DI}+\beta_{0} \\
& \mathrm{EP}=\beta_{1} \mathrm{FI}+\beta_{2} \mathrm{CI}+\beta_{3} \mathrm{SI}+\beta_{4} \mathrm{DI}+\beta_{0}
\end{aligned}
$$

Where;

IC $=$ International commitment of the firm

$\mathrm{EP}=$ Export performance of the firm

$\mathrm{FI}=$ Functional integration within the firm

$\mathrm{CI}=$ Customer integration; integration between firm and customers 
SI = Supplier integration; integration between firm and suppliers

$\mathrm{DI}=$ Distributor integration; integration between firm and distributors

Here $\beta_{1}$ through $\beta_{4}$ are slope weights for the four independent variables and $\beta_{0}$ is an additive constant.

For the determination of the model fit, "R" gives the correlation between observed and predicted values of the dependent variable. " $R$ " " is the proportion of variance of the dependent variable that is explained by the independent variables. Using "Adjusted $\mathrm{R}^{2}$ " for interpretation would be more appropriate since the original " $R$ " may sometimes present over-optimistic model fit values. The " $F$ " value is the proportion between the regression sum of squares, which is the measured variation, and the residual sum of squares, which is the unmeasured variation. Significant "F" values indicate that the portion of the explained variance is meaningfully higher than the unexplained part (Churchill, 1995). Beta $(\beta)$ values allow comparing the impact of each independent variable on the dependent variable to the effect on the dependent variable of other independent variables. Relative importance of each variable in the proposed regression model and the corresponding significance level is determined by the " $\mathrm{t}$ " values.

The assumptions of the analysis were checked before conducting multiple regression analysis which is reliability, normality, linearity and multicollinearity. Kaiser-Meyer-Olkin (KMO) Measure of Sampling Adequacy was conducted to confirm the sample size adequacy of the study. Bartlett Test of Sphericity was used to test if samples have equal variances, which is sensitive to departures for normality (Zar, 1999). Both KMO and Bartlett Test of Sphericity results are shown in Table 2.

Reliability measures the extent to which a measurement scale yields consistent results on repeated replications of the same scale. Assessing the internal consistency of items within a scale using Cronbach Alpha $(\alpha)$ is the prescribed method of establishing reliability (Cronbach, 1951). As shown in Table 3 regards to construct reliability, all indicators were over the suggested 0.70 threshold. We tested multicollinearity as a customary precaution, since its presence could be bias and effect the stability of the estimations. Both tolerance and the variance inflation factor (VIF) clearly provided consistent support for the absence of multicollinearity in the indicators (see columns 6 and 7 of Table 3). The data set fulfills the requirement of all assumptions for the multiple regression analysis.

Table 2. KMO and Bartlett's Test Results

\begin{tabular}{|c|c|c|}
\hline \multicolumn{2}{|c|}{ Kaiser-Meyer-Olkin Measure of Sampling Adequacy. } & .596 \\
\hline Bartlett's Test of Sphericity & Approx. Chi-Square & 463.211 \\
\hline & $\mathrm{df}$ & 91 \\
\hline & Sig. & .000 \\
\hline
\end{tabular}


Table 3. Reliability and Mutlicollinearity of Constructs

\begin{tabular}{|c|c|c|c|c|c|c|}
\hline Construct & Size & Mean & Std. Dev. & Cronbach Alpha & Tolerance & VIF \\
\hline \multicolumn{7}{|c|}{ Organizational Integration } \\
\hline \multicolumn{7}{|l|}{ Internal Integration } \\
\hline Functional Integration & & & & .876 & 961 & 1.041 \\
\hline $\mathrm{F} 1$ & 70 & 4.0286 & .44952 & & & \\
\hline $\mathrm{F} 2$ & 70 & 4.0000 & .41703 & & & \\
\hline F3 & 70 & 4.0000 & .45044 & & & \\
\hline \multicolumn{7}{|l|}{ External Integration } \\
\hline Customer Integration & & & & .718 & .950 & 1.053 \\
\hline CI1 & 70 & 4.0000 & .41703 & & & \\
\hline $\mathrm{CI} 2$ & 70 & 4.0143 & .43382 & & & \\
\hline $\mathrm{CI} 3$ & 70 & 4.0286 & .41603 & & & \\
\hline Supplier Integration & & & & .847 & 964 & 1.038 \\
\hline SI1 & 70 & 4.0000 & .41703 & & & \\
\hline SI2 & 70 & 4.0286 & .41603 & & & \\
\hline SI3 & 70 & 4.0143 & .43382 & & & \\
\hline Distributor Integration & & & & .728 & .949 & 1.054 \\
\hline DI1 & 70 & 4.0143 & .43382 & & & \\
\hline DI2 & 70 & 4.0286 & .41603 & & & \\
\hline DI3 & 70 & 4.0143 & .39902 & & & \\
\hline \multicolumn{7}{|l|}{ International Performance } \\
\hline IC & 70 & 3.9857 & .39902 & & & \\
\hline EP & 70 & 3.9857 & .43382 & & & \\
\hline
\end{tabular}




\section{Results}

The research hypotheses are tested by examining the direction, strength and level of significance of the path coefficients calculated by the multiple linear regressions, as shown in Table 4.

Table 4. Measurement of the model

\begin{tabular}{|c|c|c|c|c|c|c|}
\hline \multirow{3}{*}{ Independent Variables } & \multicolumn{6}{|c|}{ Dependent Variables } \\
\hline & \multicolumn{3}{|c|}{ International Commitment } & \multicolumn{3}{|c|}{ Export Performance } \\
\hline & Beta $(\beta)$ & $\mathrm{t}$ & Sig. & $\operatorname{Beta}(\beta)$ & $\mathrm{t}$ & Sig. \\
\hline Functional Integration & .229 & 2.176 & .033 & .288 & 2.789 & .007 \\
\hline Customer Integration & .264 & 2.493 & .015 & .240 & 2.311 & .024 \\
\hline Supplier Integration & .248 & 2.359 & .021 & .275 & 2.667 & .010 \\
\hline Distributor Integration & .239 & 2.261 & .027 & .212 & 2.041 & .045 \\
\hline $\mathrm{R}$ & \multicolumn{3}{|c|}{.555} & \multicolumn{3}{|c|}{.577} \\
\hline $\mathrm{R}^{2}$ & \multicolumn{3}{|c|}{.308} & \multicolumn{3}{|c|}{.333} \\
\hline Adjusted $\mathrm{R}^{2}$ & \multicolumn{3}{|c|}{.265} & \multicolumn{3}{|c|}{.292} \\
\hline $\mathrm{F}$ & \multicolumn{3}{|c|}{7.235} & \multicolumn{3}{|c|}{8.124} \\
\hline Sig. & \multicolumn{3}{|c|}{.000} & \multicolumn{3}{|c|}{.000} \\
\hline
\end{tabular}

These findings serve as the basis of evaluation for our hypotheses. The results show that the observed values of organizational integration and the values of international commitment are correlated with a coefficient of 0.555 and $31 \%$ of the variance in the international commitment are explained by organizational integration. The significant $F$ value (7.235) at 0.01 level indicates a meaningful portion of explained variance compared to the unexplained part. According to $t$ values, the effect of organizational integration on international commitment is statistically significant.

In order to interpret the results of the model, Beta values, the standardized weights associated with the regression equation, were used. These standardized weights are determined by standardizing independent and dependent variables to have a mean of " 0 " and a standard deviation of " 1 ". According to Beta values, the regression equation of our model is as follows:

International Commitment $=0.23 \mathrm{FI}+0.26 \mathrm{CI}+0.25 \mathrm{SI}+0.24 \mathrm{DI}$

Therefore,

H1: Functional integration among departments of a firm has positive significant effect on 


\section{Macrothink}

Journal of Management Research

ISSN 1941-899X

2013, Vol. 5, No. 1

international commitment since " $\mathrm{t}$ " value (2.176) confirms the effect at 0.033 significance level. $\mathrm{H} 1$ is accepted.

$\mathrm{H} 2$ : Customer integration of a firm has positive significant effect on international commitment since " $t$ " value (2.493) confirms the effect at 0.015 significance level. H2 accepted.

H3: Supplier integration of a firm has positive significant effect on international commitment since " $t$ " value (2.359) confirms the effect at 0.021 significance level. H3 is accepted.

H4: Distributor integration of a firm has positive significant effect on international commitment since "t" value (2.261) confirms the effect at 0.027 significance level. H4 is accepted.

The observed values of organizational integration and the values of export performance are correlated with a coefficient of 0.577 and $33 \%$ of the variance in the export performance is explained by organizational integration. The significant $F$ value (8.124) at 0.01 level indicates a meaningful portion of explained variance compared to the unexplained part. According to $t$ values, the effect of organizational integration on export performance is statistically significant. After the standardization of organizational integration and export performance variables, the regression equation of our model is as follows:

Export Performance $=0.29 \mathrm{FI}+0.24 \mathrm{CI}+0.28 \mathrm{SI}+0.21 \mathrm{DI}$

Therefore;

H5: Functional integration among departments of a firm has positive significant effect on export performance since " $t$ " value (2.789) confirms the effect at 0.007 significance level. H5 is accepted.

H6: Customer integration among departments of a firm has positive significant effect on export performance since " $t$ " value (2.311) confirms the effect at 0.024 significance level. H6 is accepted.

H7: Supplier integration among departments of a firm has positive significant effect on export performance since " $t$ " value (2.667) confirms the effect at 0.010 significance level. H7 is accepted.

H8: Distributor integration among departments of a firm has positive significant effect on export performance since " $t$ " value (2.041) confirms the effect at 0.045 significance level. H8 is accepted.

\section{Conclusion}

The results of this study have implications for researchers as well as for managers of exporting firms. Given the previous empirical evidences on organizational integration of firm, our results confirm that (OI) also has positive significant effect on internationalization and international performance of the firm. As discussed in the theoretical background of this study, acquiring knowledge and experience in foreign markets are the main components of the 
internationalization process. The flow of information that creates knowledge and experience is gained through integration among supply chain members. The external integration of organization is established by sharing information, collaboration and setting common performance measures among the firm, customers, suppliers and distributors.

The results of this study reveal that customer integration positively and significantly correlated with international performance, indicating that the firms with higher integration on customers tend to have higher international commitment and export performance. The most common activities in integrating the firm with customers are conducting marketing research to gather information about market and customer sensitivities, identifying customer needs and preferences in the new product development process, and collaborating with customers on solving problems as well as improving customer satisfaction.

The effect of supplier integration on international performance of a firm is confirmed by this study since results are showing positive and significant correlation between supplier integration and international commitment as well as export performance. Supplier integration occurs by sharing operational information with suppliers, collaboration in the planning of operations and achieving flexibility in operations with the help of established collaboration.

Although distributors are mainly classified as a type of supplier in literature, this study reveals the role of the distributor in the organizational integration by addressing it separately from the suppliers as a construct. As stated in Table 4, there is positive and significant correlation between distributor integration and international performance. The integration with distributors is described as sharing information about operations, collaboration in formulating the marketing strategy of the firm and setting common standards for the performance of both the firm and distributors.

The importance of internal integration in the internationalization process is also addressed within this study. It is evident that the integration among the functional departments of the firm has positive and significant effect on both international commitment and export performance. The internal integration contributes to the performance by sharing operational information among departments, establishing an integrated database to share information effectively and efficiently, and collaborating among functional department in strategic planning.

In this regard, the concept of organizational integration as operationalized in this study seems promising as exporting firms were found to vary significantly in their internal and external organizational integration.

The results and implications of this study must be considered in light of the intrinsic limitations of the survey. The nature and relatively small sample size limits the capacity to generalize research findings. Although, the total population of exporting firms operating in North Cyprus is taken as the sample in this study, the total number of respondents is significantly small (70 firms) for an academic research. In addition to this, the cross-sectional nature of the research design implies that true causal relationships between the research constructs cannot be inferred. 


\section{References}

Barki, H., \& Pinsonneault, A. (2005). A Model of Organizational Integration, Implementation Effort, and Performance. Organization Science, 16(2), 165-179. http://dx.doi.org/10.1287/orsc. 1050.0118

Benito, G. R. G., \& Welch, L. (1994). Foreign Market Servicing: Beyond Choice of Entry Model. Journal of International Marketing, 2(2), 7-27.

Bowersox, D. J. (1990). The Strategic Benefits of Logistics Alliances. Harvard Business Review, 68(4), 36-45.

Buckley, P., \& Ghauri, P. (1999). The Internationalization of the Firm. A Reader (2nd ed.), International Thomson Business Press: London.

Cagliano, R. K., \& Spina, G. (2002). A Comparison of Practice-Performance Models between Small Manufacturers and Subcontractors. International Journal of Operations \& Production Management, 22(12), 1367-1388. http://dx.doi.org/10.1108/01443570210452057

Chandler, A. (1962). Strategy and Structure: Chapters in the History of the Industrial Enterprise. Cambridge, MA: MIT Press

Chetty, S., \& Campbell-Hunt, C. (2003). Paths to Internationalization Among Small-to-Medium-Sized Firms: A Global versus Regional Approach. European Journal of Marketing, 37(5/6), 796-822.

Churchill, G. (1995). Marketing Research: Methodological Foundations. OR, Dryden Press.

Cronbach, L. (1951). Coefficient alpha and the internal structure of tests. Psychometrica, 16(3), 297-334. http://dx.doi.org/10.1007/BF02310555

Eriksson, K. (2000). Path Dependence and Knowledge Development in the Internationalization Process. Management of International Review, 40(4), 307-328.

Forrester, J. W. (1961). Industrial Dynamics, Cambridge, MA: MIT Press.

Gilmore, C., Carson, D., Grant, K., O’Donnell, A., Laney, R., \& Pickett, B. (2006). Networking in SMEs: Findings from Australia and Ireland. Irish Marketing Review, 18, 21-28.

Hammer, M., \& Champy, J. (1993). Reengineering the Corporation. New York: Harper Business. http://dx.doi.org/10.1016/S0007-6813(05)80064-3

Hines, P. (1993). Integrated Materials Management: The Value Chain Redefined. The International Journal of Logistics Management, 4(1), 13-22. http://dx.doi.org/10.1108/09574099310804920

Holweg, M., Disney, S., Holmstrom, J., \& Smaros, J. (2005). Supply chain collaboration: making sense of the strategy continuum. European Management Journal, 23(2), 170-181.

Huber, G. P., \& Power, D. J. (1985). Retrospective Reports of Strategic-Level Managers: 
Guidelines for Increasing Their Accuracy. Strategic Management Jourmal, 6(2), 171-180. http://dx.doi.org/10.1002/smj.4250060206

Johanson, J., \& Vahlne, J. E. (2003). Business relationship commitment and learning in the internationalization process. Journal of International Entrepreneurship, 1, 83-101.

Kahn, K. B., \& Mentzer, J. T. (1996). Logistics and Interdepartmental Integration. International Journal of Physical Distribution and Logistics Management, 26(8), 6-14. http://dx.doi.org/10.1108/09600039610182753

Kahn, K. B., \& Mentzer, J. T. (1998). Marketing's Integration with Other Departments. Journal of Business Research, 42(2), 53-62. http://dx.doi.org/10.1016/S0148-2963(97)00068-4

Kanter, R. M. (1994). Collaborative Advantage: The Art of Alliances. Harvard Business Review, 72(4), 96-108.

Katsikeas, C. S., Leonidou, L. C., \& Morgan, N. A. (2000). Firm-Level Export Performance Assessment: Review, Evaluation, and Development. Academy of Marketing Science, 28(4), 493-511. http://dx.doi.org/10.1177/0092070300284003

Knight, G. A., \& Cavusgil, S. T. (2004). Innovation, Organizational Capabilities, and the Born-Global Firm. Journal of International Business Studies, 35(2), 124-141. http://dx.doi.org/10.1057/palgrave.jibs.8400071

Lumpkin, G. T., \& Dess, G. G. (2001). Linking Two Dimensions of Entrepreneurial Orientation to Firm Performance: The Moderating Role of Environment and Industry Life Cycle. Journal of Business Venturing, 16(5), 429-451.

McLaren, T. S., Head, M. M. \& Yuan, Y. (2004). Supply Chain Management Information Systems Capabilities: An Exploratory Study of Electronics Manufacturers. Information Systems and e-Business Management, 2(2), 207-222.

Olkkonen, R., Tikkanen, H., \& Alajoutsijärvi, K. (2000). The role of communication in business relationships and networks. Management Decision, 38(6), 403-409. http://dx.doi.org/10.1108/EUM0000000005365

Osarenkhoe, A. (2010). A coopetition strategy-a study of inter-firm dynamics between competition and cooperation. Business Strategy Series, 11(6), 343-362. http://dx.doi.org/10.1108/17515631011093052

Porter, M. E. (1985). Competitive Advantage: Creating and Sustaining Superior Performance. New York: The Free Press.

Porter, M.E. (1998). Clusters and the new economics of competition. Harvard Business Review, 76 (6), 77-90.

Shapiro, B., Rangan, V. K., \& Sviokla, J. J. (1992). Staple Yourself to an Order. Harvard Business Review, 70(4), 113-122. http://dx.doi.org/10.1016/0024-6301(93)'90305-Y 
Soshko, O. (2011). Model-based supply chain management. Scientific Journal of Riga Technical University, 49, 116-117. http://dx.doi.org/10.2478/v10143-011-10052-z

Stadtler, H. (2009). A Framework for Collaborative Planning and State-of-the-Art. OR Spectrum, 31, 5-30. http://dx.doi.org/10.1007/s00291-007-0104-5

Stank, T. P., Keller, S. B., \& Daugherty, P. J. (2001). Supply chain collaboration and logistical service performance. Journal of Business Logistics, 22(1), 29-47. http://dx.doi.org/10.1002/j.2158-1592.2001.tb00158.x

Staude, G. E. (1987). The Physical Distribution Concept as a Philosiophy of Business. International Journal of Physical Distribution and Materials Management, 17(6), 32-37. http://dx.doi.org/10.1108/eb014665

Stevens, J. (1989). Integrating the supply chain. International Journal of Physical Distribution and Materials Management, $\quad$ 19(8), http://dx.doi.org/10.1108/EUM0000000000329

Tan, K., Kannan, V., \& Handfield, R. (1998). Supply chain management supplier performance and firm performance. International Journal of Purchasing and Materials Management, 34(3), 2-9.

Treacy, M., \& Wiersema, F. (1993). Customer Intimacy and Other Value Disciplines. Harvard Business Review, 71(1), 84-93.

Vereecke, A., \& Muylle, S. (2006). Performance improvement through supply chain collaboration in Europe. International Journal of Operations and Production Management, 26(11), 1176-1198.

Vickery, S. K., Jayaram, J., Droge, C., \& Calantone, R. (2003). The effects of an integrative supply chain strategy on customer service and financial performance: an analysis of direct versus indirect relationships. Journal of Operations Management, 21(5), 523-539. http://dx.doi.org/10.1016/j.jom.2003.02.002

Waite, P., \& Williams, P. (2009). Collaboration or opportunism? The role of social capital in developing successful export clusters. Journal of Strategic Marketing, 17(6), 499-512. http://dx.doi.org/10.1080/09652540903371752

Zar, J. H. (1999). Biostatistical Analysis. 4th edn. Upper Saddle River, NJ: Prentice-Hall.

\section{Copyright Disclaimer}

Copyright reserved by the author(s).

This article is an open-access article distributed under the terms and conditions of the Creative Commons Attribution license (http://creativecommons.org/licenses/by/3.0/). 